\title{
Mukopolisakkaridozlarda ortopedik sorunlar
}

\author{
Orthopedic problems in mucopolysaccharidoses
}

\author{
Yılmaz Yıldız, H. Serap Sivri
}

Hacettepe Üniversitesi Tıp Fakültesi, Çocuk Sağlığı ve Hastalıkları Anabilim Dalı, Çocuk Metabolizma Bilim Dalı, Ankara

Lizozomal enzimlerin kalıtsal eksiklikleri nedeniyle ortaya çıkan lizozomal depo hastalıklarından mukopolisakkaridozlar, iskelet bulgularının şiddeti ve çeşitliliği ve nedeniyle ortopedistler açısından önem taşımaktadır. Büyüme geriliği, servikal instabilite, kraniyoservikal bileşke darlığı, kifoz, karpal tünel sendromu, tetik parmak, kalça displazisi ve genu valgum, mukopolisakkaridozlarda görülen başlıca ortopedik sorunlardır. Bu sorunlar, genellikle cerrahi girişim gerektirmektedir. Mukopolisakkaridozlu hastaların izlemleri ve tedavileri, içinde ortopedistlerin de yer aldığı multidisipliner ekiplerce yönetilmelidir.

Anahtar sözcükler: mukopolisakkaridozlar; dizostozis multipleks; pediatri

izozomal depo hastalıkları, lizozomal enzim eksiklikleri nedeniyle oluşan kalıtsal metabolik hastalıklardır. Lizozomal depo hastalıkları arasında en çarpıcı ve çeşitli, çoğu zaman cerrahi müdahale gerektiren ortopedik bulgular mukopolisakkaridozlarda görüldüğünden, bu yazıda mukopolisakkaridozların ortopedik bulgularına değinilecektir. Mukopolisakkaridozlar (MPS'ler), bağ dokunun yapısal bileşenlerinden olan glikozaminoglikanların lizozomda yıkımını sağlayan çeşitli asit hidrolazların eksikliği sonucu gelişen, kronik, ilerleyici ve çok sayıda sistemi etkileyen bir hastalık grubudur. Etkilenen enzim ve biriken glikozaminoglikana göre klinik ve biyokimyasal olarak birbirinden ayrılan yedi MPS tipi (MPS Tip I, II, III, IV, VI, VII, ve IX) bilinmektedir. MPS'lerin klinik bulguları arasında; kaba yüz görünümü, gelişim geriliği, mental retardasyon, tekrarlayan otitis media, işitme kaybı, adenotonsiller hipertrofi, korneal bulanıklık, restriktif akciğer hastalığı, valvuler kalp hastalığı, hepatosplenomegali, inguinal ve umbilikal herni, boy kısalığı, eklem kontraktürleri,
Among the lysosomal storage diseases which arise due to inherited deficiencies of lysosomal enzymes, mucopolysaccharidoses are important for orthopedic surgeons due to their severe and vast skeletal manifestations. Short stature, cervical instability, stenosis of the craniocervical junction, kyphosis, carpal tunnel syndrome, trigger finger, hip dysplasia and genu valgum are the cardinal orthopedic problems in mucopolysaccharidoses. These problems usually require surgical interventions. Follow-up and treatment of patients with mucopolysaccharidosis must be managed by multidisciplinary teams which include orthopedic surgeons.

Key words: mucopolysaccharidoses; dysostoses multiplex; pediatrics

kemik deformiteleri yer almaktadır. MPS tiplerinin genel bulguları Tablo 1'de, tiplerinin ayırt edici özellikleri Tablo 2'de özetlenmiştir. MPS hastalarının genel görünümünde dikkat çekici klinik bulgular ise Şekil 1'de sunulmuştur. X'e bağlı resesif kalıtılan MPS Tip II dışında tüm MPS tipleri otozomal resesif geçiş gösterir. ${ }^{[1]}$

MPS'lerde, endokondral ve membranöz kemikleşmedeki yaygın gecikme ve bozukluk nedeniyle, klasik olarak görülen radyografik kemik anomalilerinin bütünü dizostozis multipleks olarak adlandırılır. Dizostozis multipleksin bileşenleri arasında; skolyozun da eşlik edebildiği kifoz, femur başının subluksasyonu veya dislokasyonuna yol açabilen, asetabulumların sığ olarak izlendiği kalça displazisi, genu valgum, geniş kraniyum ve kalın kalvariyum, J şeklinde genişlemiş sella turcica, genişleyerek spatula görümü almış klavikula ve kostalar, uzun kemiklerde hipoplastik epifizler ile kalınlaşmış, kaba diyafizler ve kurşun şeklini almış kısa metakarpal kemikler yer alır (Şekil 2). ${ }^{[4]}$

- Illetişim adresi: Prof. Dr. H. Serap Sivri, Hacettepe Üniversitesi İhsan Doğramacı Çocuk Hastanesi, 5. Kat Çocuk Metabolizma Bilim Dalı, Sıhhiye, Ankara Tel: 0312 - 3051141 e-posta: ssivri@hacettepe.edu.tr

- Geliş tarihi: 8 Ağustos 2016 Kabul tarihi: 8 Ağustos 2016 
Tablo 1. Mukopolisakkaridozlarda klinik bulgular ${ }^{[1,2]}$

\begin{tabular}{|c|c|}
\hline \multicolumn{2}{|l|}{ Nörolojik } \\
\hline & o Gelişsme geriliği \\
\hline & o Zihinsel engellilik (mental retardasyon) \\
\hline & o Davranış sorunları \\
\hline & o Baş ağrısı \\
\hline & o Non-obstrüktif hidrosefali \\
\hline & o Medulla spinalis basısı \\
\hline & o Epilepsi \\
\hline & o Tuzak nöropatiler \\
\hline \multicolumn{2}{|c|}{ Otorinolaringolojik } \\
\hline & o İşitme kaybı \\
\hline & o Adenotonsiller hipertrofi \\
\hline & o Tekrarlayan otitis media \\
\hline & o Obstrüktif uyku apnesi \\
\hline \multicolumn{2}{|c|}{ Oftalmolojik } \\
\hline & o Korneal bulanıklık \\
\hline & o Glokom \\
\hline & o Retinopati \\
\hline & o Papilödem \\
\hline \multicolumn{2}{|c|}{ Kardiyovasküler } \\
\hline & o Kardiyomiyopati \\
\hline & o Valvuler kapak hastalığı \\
\hline \multicolumn{2}{|l|}{ Pulmoner } \\
\hline & o Göğüs kafesi deformiteleri \\
\hline & o Restriktif akciğer hastalığı \\
\hline & o Reaktif hava yolu hastalığı \\
\hline & o Tekrarlayan akciğer enfeksiyonları \\
\hline \multicolumn{2}{|l|}{ Ortopedik } \\
\hline & o Eklem sertliği/laksitesi \\
\hline & o Eklem ağrısı \\
\hline & o Boy kısalığı \\
\hline & o Spinal deformiteler \\
\hline & o Genu valgum \\
\hline & o Kalça displazisi \\
\hline \multicolumn{2}{|c|}{ Gastrointestinal } \\
\hline & o Hepatomegali \\
\hline & o Splenomegali \\
\hline & o İnguinal herni \\
\hline & o Umbilikal herni \\
\hline & o İshal \\
\hline & o Beslenme güçlüğü \\
\hline \multicolumn{2}{|l|}{ Dental } \\
\hline & o Çürükler \\
\hline & o Periodontal hastalıklar \\
\hline & o Oklüzyon bozuklukları \\
\hline
\end{tabular}

MPS Tip I, II, VI ve VII'de ortopedik bulgular daha çok dizostozis multipleks ve eklem kontraktürleri şeklinde iken, Tip IV'te bundan farklı olarak eklemlerde laksite ve hipermobilite, odontoid displazi ile seyreden ağır bir iskelet displazisi mevcuttur. MPS Tip III ise, iskelet bulguları ve viseral tutulumun daha silik olduğu, hiperaktivite ve otistik davranışlar gibi davranışsal sorunlar ile başlayıp ilerleyici ve ağır mental yıkım ile seyreden bir fenotip ile karakterizedir. ${ }^{[4]}$ Geçmiş yıllarda MPS'lerin çoğu erken çocukluk döneminde fatal seyirli iken, MPS Tip I'de hematopoietik kök hücre transplantasyonu (HKHT), MPS Tip I, II, IVA ve VI'da enzim replasman tedavisi (ERT) hastalığın seyri üzerinde olumlu etkiler göstererek beklenen yaşam süresini uzatmıştır; diğer MPS tipleri için ERT geliştirilmesi çalışmaları ve bazı tipler için gen tedavisi çalışmaları sürmektedir. ERT, hastalığın birçok somatik bulgusu üzerinde olumlu etki gösterirken, enzimin kemik ve kıkırdak dokusuna penetrasyonunun kötü olması nedeniyle, yerleşmiş iskelet deformitelerini geri döndürebilen bir medikal tedavi henüz geliştirilememiştir. Erken tanı ve tedavinin özellikle somatik bulgular üzerindeki olumlu etkisi nedeniyle, ortopedistlerin MPS'leri tanımaları ve hastalığın ya da komplikasyonlarının tanısal ve girişimsel süreçleri hakkında bilgi sahibi olmalarının önemi giderek artmaktadır. ${ }^{[5]}$ Bu derlemede; MPS'lerde hayat kalitesini etkileyen önemli ortopedik sorunlardan büyüme geriliği, eklem kontraktürleri, spinal deformiteler, karpal tünel sendromu, tetik parmak, kalça displazisi ve genu valgum üzerinde durulacaktır. Ayrıca, MPS'lerde görülen ortopedik sorunlara yönelik medikal ve cerrahi tedavi seçenekleri ile cerrahi girişimlerde dikkat edilmesi gereken bazı noktalara kısaca değinilecektir.

\section{BÜYÜME GERILiĞi}

Boy kısalığı, tüm MPS tiplerinde görülen bir bulgudur. Boy kısalığı orantısız tipte olup kısalık gövdede daha belirgindir; ancak, ekstremitelerde de kısalık mevcuttur. Endokondral ossifikasyonun büyüme

Tablo 2. Mukopolisakkaridoz tiplerinde ayırt edici özellikler ${ }^{[3]}$

\begin{tabular}{|c|c|c|c|c|c|c|}
\hline & MPS Tip I & MPS Tip II & MPS Tip III & MPS Tip IV & MPS Tip VI & MPS Tip VII \\
\hline Kaba, dismorfik yüz & $(+)$ & \pm & \pm & - & + & \pm \\
\hline Mental retardasyon & $(+)$ & \pm & + & - & - & \pm \\
\hline Korneal bulanıklık & + & - & - & $(+)$ & + & \pm \\
\hline Boy kısalığı & $(+)$ & + & - & + & + & + \\
\hline Eklem kontraktürleri & + & + & - & - & + & + \\
\hline Organomegali & $(+)$ & + & $(+)$ & - & + & + \\
\hline
\end{tabular}

Hastalık tipinde; +, belirgin olarak bulunması beklenir; (+), olması beklenir, bazı olgularda bulunmayabilir; \pm , hafif şiddette bulunması beklenir; -, bulunması beklenmez. 

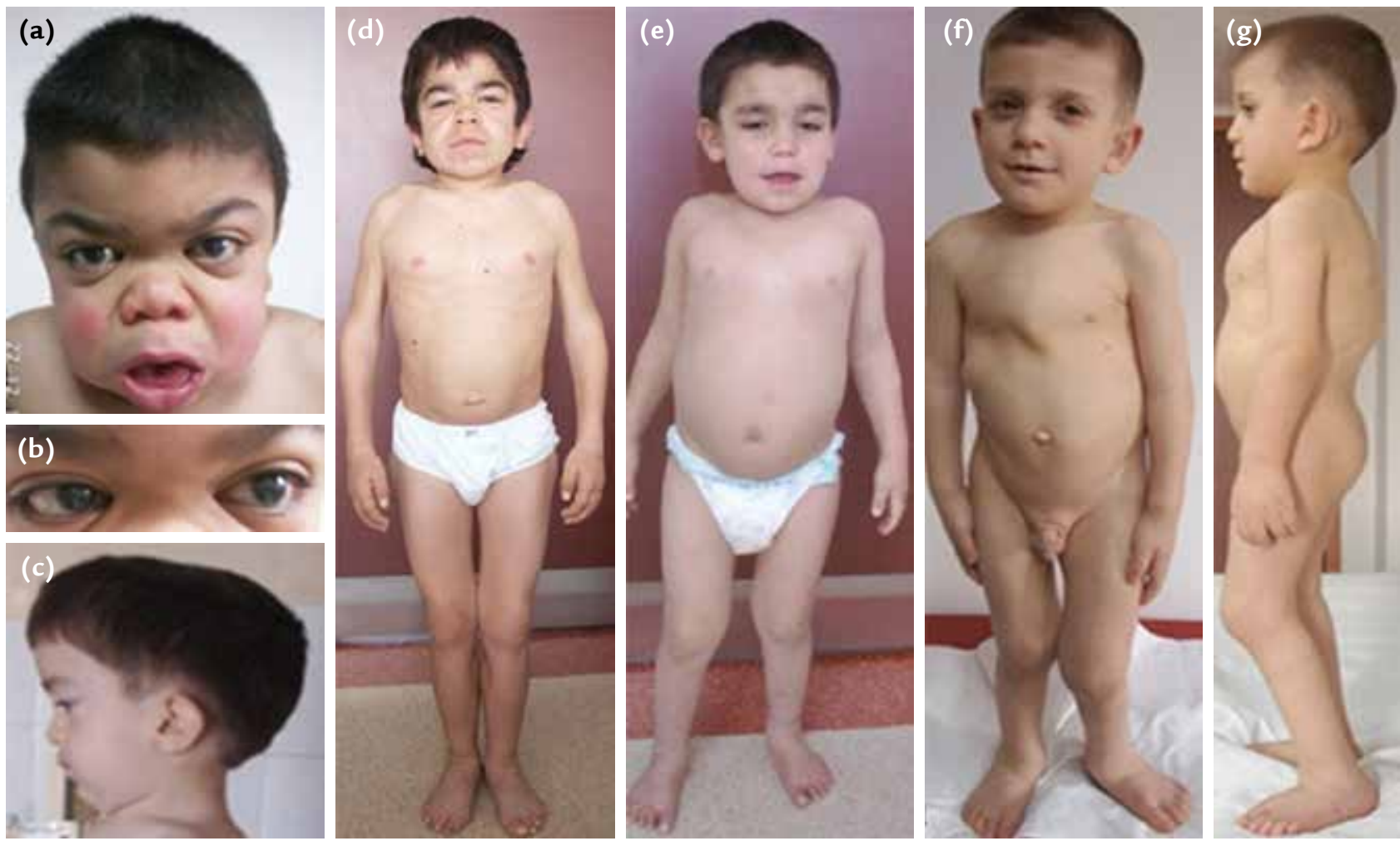

Şekil 1. a-g. MPS hastalarında genel görünüm. ${ }^{[2]}$ MPS Tip I hastasında tipik yüz görünümü: Kaba yüz, frontal belirginleşme, basık burun kökü, büyük ağız, makroglossi (a). Korneal bulanıklık (b). MPS Tip Vı hastasında skafosefali (c). MPS Tip II hastasında kaba yüz görünümü, rizomeli (d). MPS Tip III hastasında yüz ve iskelet bulguları belirgin olmaksızın mental retarde görünüm (e). MPS Tip IV hastasında kısa boyun, pektus karinatum, kosta deformiteleri, boy kısalığı, kifoskolyoz, genu valgum (f, g).
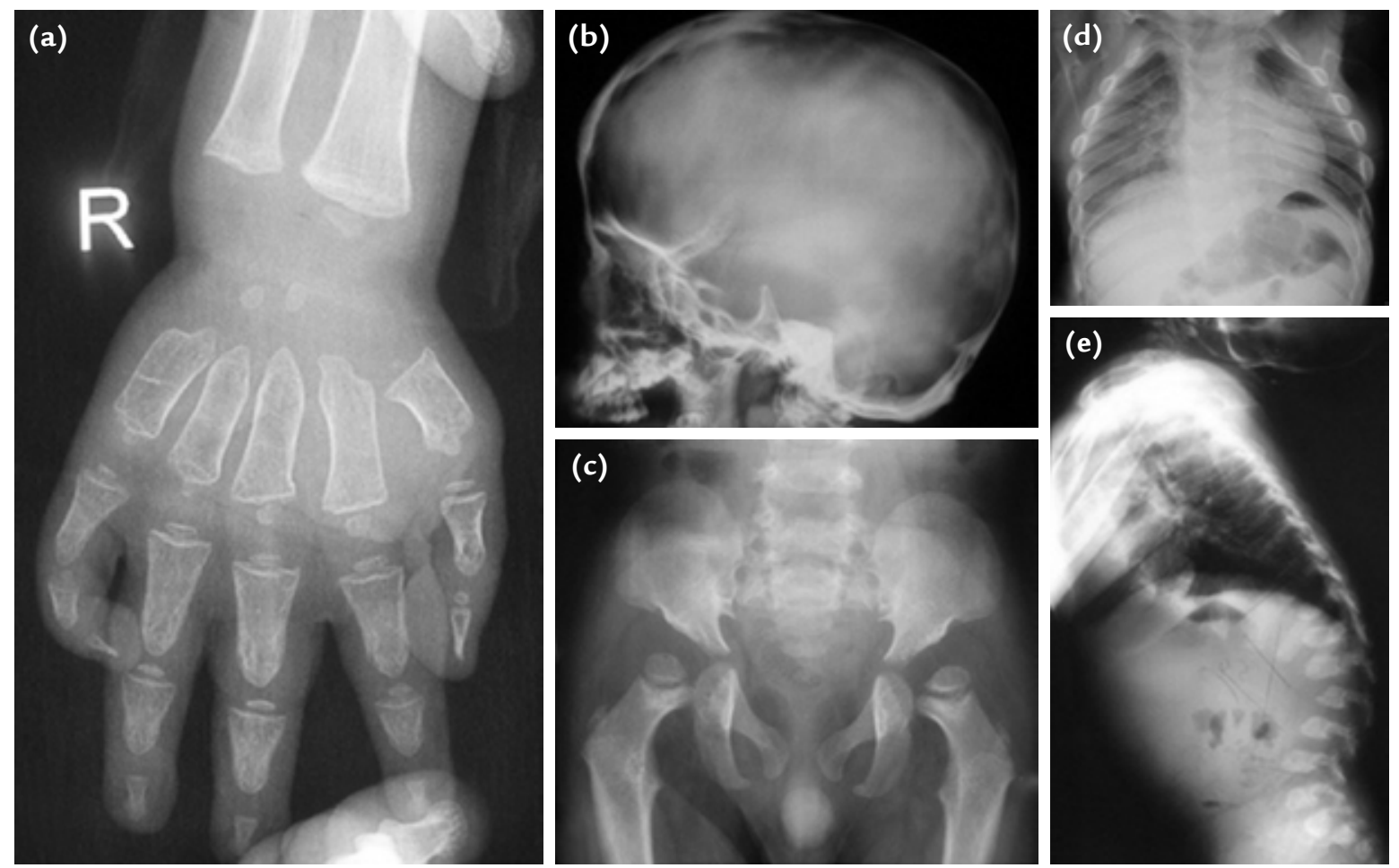

Şekil 2. a-e. Dizostozis multipleks. ${ }^{[2]}$ Metakarpal kemiklerde proksimal sivrileşme (a). J-sella görünümü (b). Asetabular düzensizlik, küçük iliak kanatlar (c). Kostalarda genişleme, spatula kosta görünümü (d). Kifoz, vertebra korpuslarında anteriora doğru yassılaşma, gagalaşma (e). 

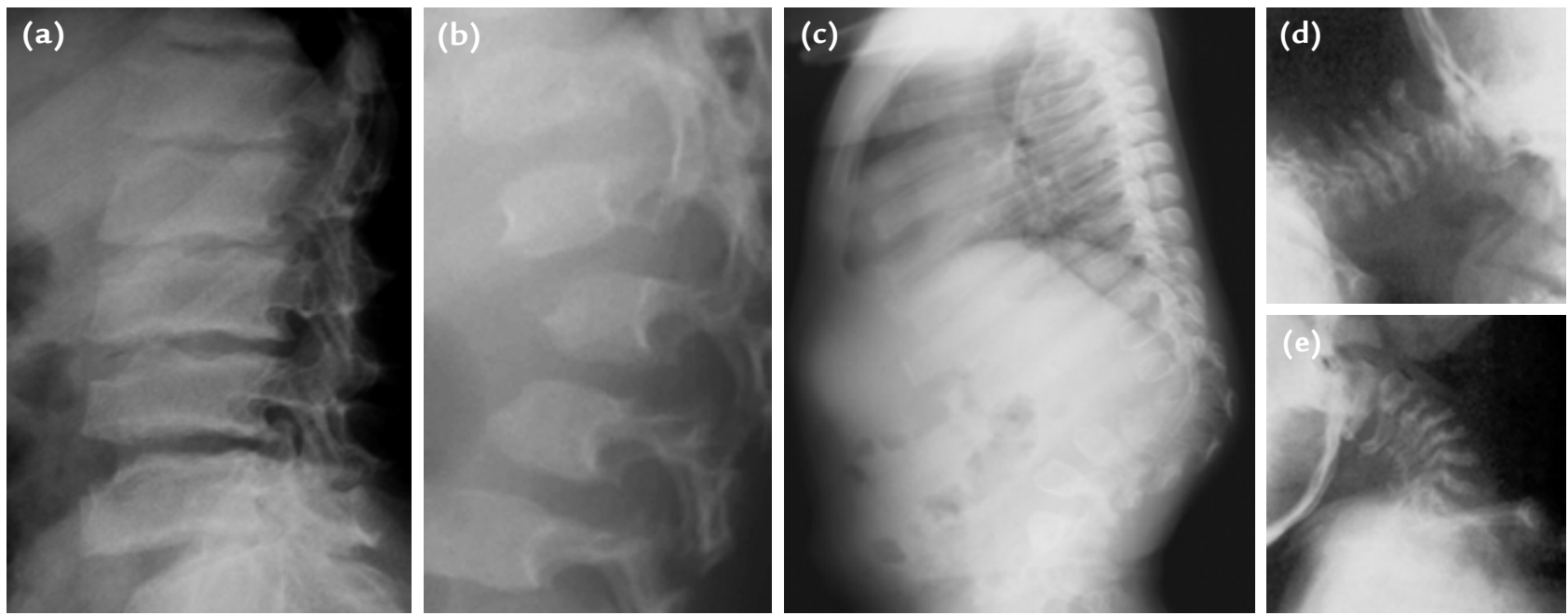

Şekil 3. a-e. MPS'lerde spinal radyografi bulguları. ${ }^{[12]}$ Platispondili, dejeneratif artrit (a). Vertebra korpuslarının anteriorunda gagalaşma, çentikleşme (b). Torakolomber kifoz (c). Fleksiyon (d) ve ekstansiyon (e) grafilerinde servikal instabilite.

plağındaki glikozaminoglikan birikimine bağlı gecikmesine ek olarak, endokrinopatinin ve beslenme bozukluğunun da boy kısalığına yol açan bileşenler arasında olduğu düşünülmektedir. Ayrıca, kifoz ve genu valgum gibi yapısal bozukluklar da boy kısalığını derinleştirir. ${ }^{[4]}$

MPS'ye bağlı boy kısalığında, insan rekombinan büyüme hormonunun büyüme hızını arttırdığı bildirilmiş olsa da kullanımı tartışmalıdır. ${ }^{[6]}$ ERT'nin büyüme geriliğinde olumlu etkileri olduğu düşünülse de, bu yönde görüş birliği bulunmamaktadır. ${ }^{[7]}$ Bebeklik döneminde HKHT yapılan ya da ERT başlanan MPS hastalarının boylarının, tedaviye daha geç başlanmış kardeşlerinden daha uzun olduğunu bildiren yayınlar mevcuttur. ${ }^{[8-10]}$

\section{MPS HASTALARINDA SPINAL DEFORMITELER}

Dizostozis multipleksin spinal bileşenleri arasında; platispondili, vertebra anteriorunda gagalaşma, torakolumbar kifoz bulunur. Hastalık ilerledikçe, bu tabloya dejeneratif artrit bulguları da eklenir (Şekil 3). [11]

\section{Servikal İnstabilite}

Atlanto-aksiyel instabilite (Şekil 3d ve 3e), yaygın eklem laksitesinin tabloya hakim olduğu MPS Tip IV'te en belirgindir. Bu tablonun, odontoid proçes (dens) hipoplazisinin yanı sıra, eklem çevresindeki bağlarda güçsüzlük sonucu da geliştiği düşünülmektedir. Odontoid proçesin ossifikasyonunun gecikmesi ve kıkırdak yapıda kalması, bu bölgenin tekrarlayan travmalara duyarlı kalmasına ve bazen kırılmasına neden olmaktadır. Odontoid kırı̆ı̆, hipoplazinin ve bağ doku laksitesinin yaratmış olduğu atlanto-aksiyel instabiliteyi arttırmaktadır. Atlantoaksiyel instabilite, fleksiyon-ekstansiyon direkt grafilerinde her zaman görüntülenemeyebilir; o takdirde floroskopi ya da dinamik bilgisayarlı tomografi yardımcı olabilir. ${ }^{[4]}$

\section{Kraniyoservikal Bileşke Stenozu}

Odontoid travmalarının yol açtığı diğer bir servikal sorun, odontoid proçes çevresinde kıkırdak ve fibröz dokunun hipertrofisidir. Atlanto-aksiyel instabilite ile birlikte periodontoid bağ dokusu hipertrofisi ve bölgedeki glikozaminoglikan birikimi, kraniyoservikal bileşke stenozuna ve kord basısı gelişmesi durumunda servikal miyelopatiye yol açar. Miyelopatiye ikincil gelişen kuadriparezi, MPS Tip IV ve VI'nın iyi bilinen bir komplikasyonu olup, erken ölüm nedenleri arasında yer almaktadır. ${ }^{[4]}$

Öykü ve fizik muayeneye ek olarak elektrofizyolojik çalışmalar (somatosensory evoked potentials [SSEP]) ve manyetik rezonans (MR) görüntüleme, servikal stenoz ve miyelopatinin tanısında önem taşımaktadır (Şekil 4). ${ }^{[13,14]}$ Miyelopati yönünden, asemptomatik MPS hastalarının SSEP ve servikal MR ile aralıklı olarak değerlendirilmesi önerilmekle birlikte takip sıklı̆̆ı ya da cerrahi girişimin zamanlaması ve yöntemi konusunda görüş ayrılıkları bulunmaktadır. Dekompresyon ve füzyonun MPS Tip IV'te erken yaşta profilaktik olarak yapılmasını öneren araştırmacılar olsa da, füzyon önermeyen ve dekompresyon için daha ileri yaşları tercih eden gruplar da bulunmaktadır. ${ }^{[4,13,14]}$ 

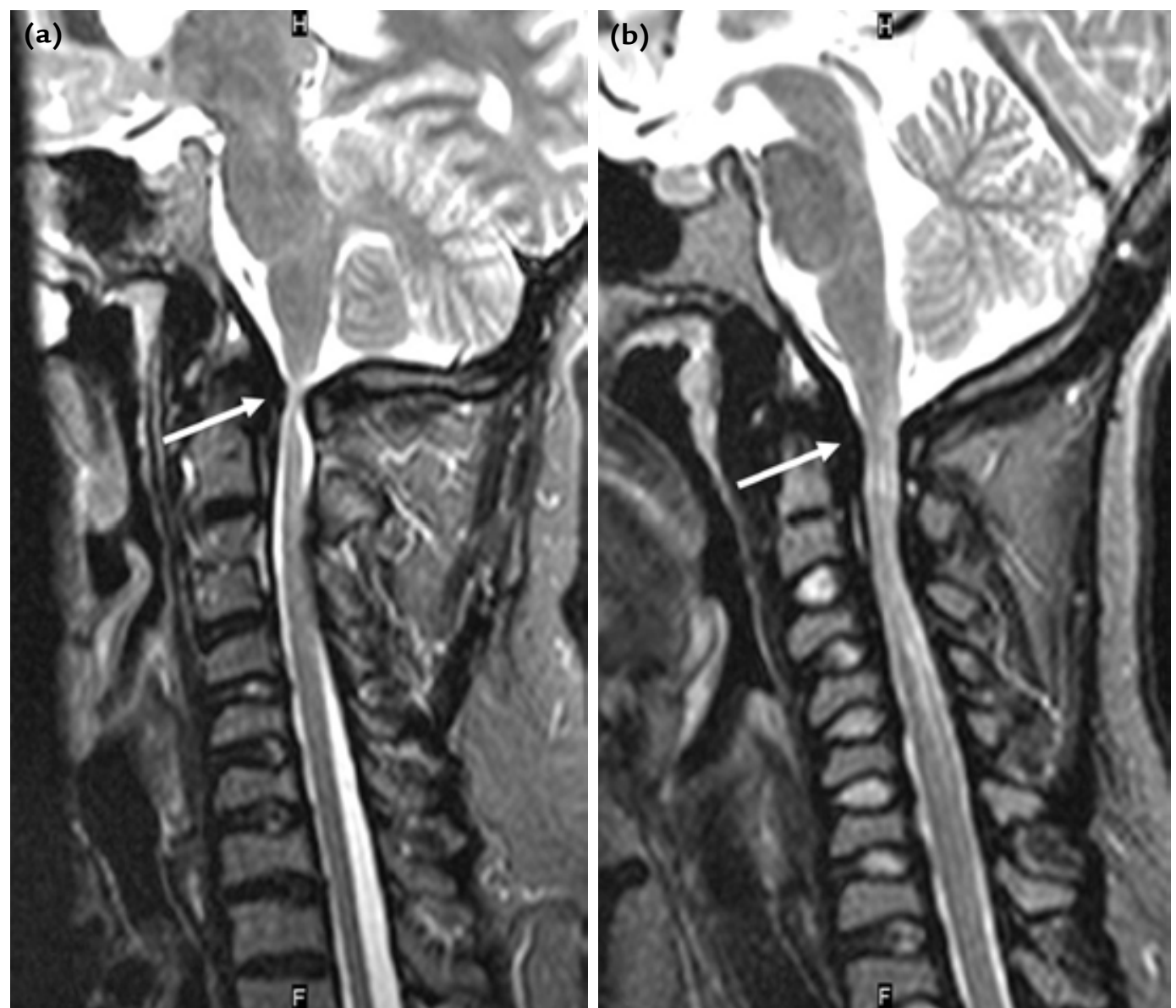

Şekil 4. a, b. Erişkin yaştaki MPS Tip VI tanılı iki kardeşte kraniyoservikal bileşke darlığı. Şiddetli darlığı olan 24 yaşındaki ağabeyde alt ekstremitelerde spastisite, derin tendon reflekslerinde hiperaktivite, yürüme güçlüğü, paresteziler mevcutken (a), 17 yaşındaki kız kardeşinde miyelopatinin klinik bulguları yoktu (b).

\section{Kifoz}

Torakolomber kifoz (gibbus deformitesi), MPS'lerin en belirgin ortopedik bulgusudur. Tüm MPS tiplerinde bildirilmiş olup, ağır MPS Tip I, IV ve VI olgularının hemen hepsinde mevcuttur. Kifoz, üst lomber vertebra korpuslarının anterior-superior kısımlarının yetersiz kemikleşmesinden dolayı meydana gelir. Bu süreç, torakolomber bileşkede anterior kamalaşma, retrolistezis ve intervertebral disklerin anterior herniyasyonu ile sonuçlanır. MPS Tip I ve VI'da, kifozun ilerlemesini engelleme amaciyla, genellikle cerrahi girişim gerekmektedir. Bazı olgularda skolyoz da mevcut olup, daha nadiren cerrahi gerektirir. ${ }^{[4,12]}$

MPS'de kifoza yönelik korse kullanımını destekleyen klinik veri bulunmamaktadır. Boy kısalığı, karın çevresinde genişlik gibi nedenlerle, MPS'li çocuklarda korse özellikle rahatsız edici olmakta, genellikle tolere edilmediği için kullanılmamaktadır. Cerrahinin uygun olmadığı, deformitesi ilerleyici olan küçük çocuklarda kullanılması düşünülebilir. ${ }^{[4]}$

\section{MPS HASTALARINDA ÜST EKSTREMITELERDE GÖRÜLEN ORTOPEDIK SORUNLAR}

Omuz, dirsek ve el bileği eklemlerindeki kontraktürlere bağlı hareket kısıtlılığı, MPS hastalarında hayat kalitesini etkileyen önemli güçlüklere yol açar. Günlük yaşam aktivitelerini oldukça güçleştirebilen bu yakınmalar, çocukluk çağında motor gelişimin de yaşıtlarından geri kalmasına yol açan etmenlerdendir. Metakarpofalangeal ve interfalangeal eklem kontraktürleri ile karpal tünel sendromunun birlikte yol açtı̆̆ı "pençe el" deformitesi, MPS'ler için oldukça karakteristiktir. Ayrıca, karpal kemiklerdeki ossifikasyon 
gecikmesi nedeniyle, MPS'li hastalarda kemik yaşı geriliği saptanmaktadır. Eklem hareketlerinde kısıtlılık dışında, MPS'de oldukça özgül üst ekstremite bulguları arasında, karpal tünel sendromu ve tetik parmak üzerinde durulmalıdır. ${ }^{[5]}$

\section{Karpal Tünel Sendromu}

Karpal tünel sendromu (KTS), erişkinlerde oldukça sık görülen bir sorun olmakla beraber, çocuklarda hemen her zaman altta yatan bir hastalığa bağlı olup, mutlaka patolojik olarak değerlendirilmelidir. Çocukluk çağında KTS tanısı alan 163 hastalık bir seride, etiyolojik neden olarak MPS'ler, 95 hasta (\%58) ile ilk sırada yer almıştır. ${ }^{[15]}$ Karpal kemiklerde, karpal tünelin içindeki tendonlarda ve tendon kılıflarında glikozaminoglikanların birikimi, mediyan sinirde basınç artışı ve kompresyona yol açar. MPS'li çocuklarda mediyan sinirin işlevi kayboluncaya kadar, KTS'nin his kaybı, parestezi, ağrı gibi klasik semptomları hiç bildirilmeyebilir. Bu durum, hastaların yaşının küçük olması, bilişsel ve dil gelişimindeki gecikme, eklem kontraktürlerinin belirtileri maskelemesi, bulguların yavaş gelişmesi, hastalığın hayatı tehdit edici tutulumları nedeniyle bu belirtilerin önemsenmemesi gibi birçok nedene bağlı olabilir. Dolayısıyla; tırnak yeme (his kaybı ile ilişkili), başkalarının elini tutmaktan kaçınma, ince motor becerilerde gerileme, giderek artan sakarlık, terlemede azalma, gece ağrı ile uyanma gibi belirtilerin bu hasta popülasyonunda erken uyarıcı özgül bulgular olabileceği yönündeki bildirimler, erken tanı açısından önemlidir. ${ }^{[5]}$ Elektrofizyolojik çalışmalar (elektronöromiyografi [ENMG]), KTS şüphesi olan MPS hastalarında mutlaka endikedir. Ancak, belirtilerin silikliği, gözden kaçabilmesi ve progresyonun izlemini sağlaması amacıyla, MPS'li hastalarda belirli aralıklarla tarama testi olarak kullanılması da bazı yazarlarca önerilmektedir. KTS tanısı, MPS'li çocuklarda cerrahi dekompresyon endikasyonu oluşturmaktadır. ${ }^{[5,15]}$

\section{Tetik Parmak}

MPS'lerde tetik parmak prevalansı da artmıştır. Parmak eklemlerindeki glikozaminoglikan birikimini, tetik parmağa yol açan fleksör tendon tutulumundan ayırt etmek güç olabilir. Bu nedenle, tüm MPS hastalarında tetik parmak belirtilerinin sorgulanması, tüm parmakların hareket kısıtlılığı açısından muayene edilmesi, fleksiyon kontraktürleri ile aktif ve pasif harekette tetiklemenin değerlendirilmesi, özellikle A1 makara sistemindeki fleksor tendon depolanmalarının palpe edilmesi gerekmektedir. $^{5}$ Tetik parmaklı çocuklarda, önce izlem, fizik tedavi ve atelleme gibi konservatif tedaviler tercih edilmeli; belirtiler uzun süre devam ederse cerrahi girişim planlanmalıdır. ${ }^{[16]}$

\section{MPS HASTALARINDA \\ ALT EKSTREMITELERDE GÖRÜLEN ORTOPEDIK SORUNLAR}

MPS'li hastalarda alt ekstremite eklemlerinin tutulumu da, üst ekstremiteye benzer şekilde, hayat kalitesini etkileyen, özellikle mobilizasyonu güçleştiren sorunlara neden olmaktadır. En ağır ve önemli bulgular, kalça ve diz eklemlerinde görülmektedir.

\section{Kalça Displazisi}

Kalça displazisi, dizostozis multipleksin başlıca bulgularındandır; MPS'nin tüm tiplerinde gözlenebilir. Asetabulum ve proksimal femur epifizinde gelişme geriliği nedeniyle, asetabulum yassı olarak izlenir. Hastalık bulguları ilerledikçe yıllar içerisinde femur başının küreselliği azalır, femur laterale doğru göç eder [17]; progresif kalça instabilitesi ve geç dönemde dislokasyon ile sonuçlanır. Bu durum, avasküler femur başı nekrozu için risk oluşturur. ${ }^{[4]}$

Tedavide abduksiyon korsesi muhtemelen etkisiz olup, bu yaklaşımın kas güçsüzlüğünü arttırdı̆̆ı ve fiziksel gelişmeyi geciktirdiği düşünülmektedir. ${ }^{[4]}$ HKHT ve ERT yaklaşımlarının kemik dokuya etkisinin yetersiz olması nedeniyle, kalça displazisi de bu tedavilere yanıt vermemekte, bu nedenle özellikle kalça displazisinin en yaygın izlendiği grup olan ağır fenotipteki MPS Tip I hastalarında erken dönemde cerrahi girişim gerekebilmektedir. ${ }^{[18]}$ Osteonekroz riski nedeniyle MPS Tip III ve IV'te kalça cerrahisinin rolü tartışmalıdır. Kalça displazisinin progresyonunu takip için, düzenli aralıklarla anteroposterior pelvis grafilerinin çekilmesi önerilmiştir. ${ }^{[4]}$

\section{Genu Valgum}

Cerrahi gerektirecek şiddette genu valgum, MPS Tip IV hastalarının hemen hepsinde, ağır fenotipli MPS Tip I hastalarının yarısından fazlasında, MPS Tip VI ve hafif fenotipli MPS Tip I hastalarının da bir kısmında gelişmektedir. Tibiofemoral açının $15^{\circ}$ 'yi aşmasının cerrahi endikasyonu oluşturduğu öne sürülmüştür. ${ }^{[7]}$ Osteotomiye kıyasla daha az girişimsel olması, mobiliteyi daha az azaltması nedeniyle, hemiepifizyodezis tercih edilen yaklaşım olsa da, MPS'li hastalarda büyümenin nasıl ve ne kadar devam edeceğini öngörmek güç olduğundan, girişimin zamanı ve yöntemine karar vermek de zor olabilmektedir. ${ }^{[19]}$ Osteotomi, daha invaziv olmakla birlikte, büyüme modülasyonu için çok küçük olan ya da 
kalan büyüme potansiyeli yetersiz olan çocuklarda tercih edilebilmektedir. ${ }^{[7]}$

\section{MUKOPOLISAKKARIDOZLARDA CERRAHI GIRIŞiMLER VE ANESTEZi}

MPS hastaları, anestezi komplikasyonları açısından artmış risk altındadır. Kardiyomiyopati veya valvuler kapak hastalıkları olan hastalar, ameliyat öncesi kardiyolojik açıdan değerlendirilmelidir. Kosta deformiteleri, kifoz, skolyoz ya da akciğer tutulumu nedeniyle, restriktif akciğer hastalığı olan hastaların göğüs hastalıkları uzmanı tarafından incelenmesi, koopere olabilen hastalarda solunum fonksiyon testlerinin yapılması uygundur. Merkezi sinir sistemi tutulumuna bağlı epilepsisi olan hastaların antiepileptik ilaçlarının ameliyat öncesi düzenlemesi ve kanama bozukluğu, transaminaz yüksekliği gibi ilaç yan etkileri açısından değerlendirilmesi gerekebilir. Ayrıca, makroglossi, adenotonsiller hipertrofi, laringotrakeal darlık nedeniyle hastaların entübasyonu güç olup, servikal instabilite, entübasyon sırasında pozisyon verirken risk oluşturmaktadır. Güvenli hava yolu sağlanmasında güçlük yaşanırsa acil trakeostomi açılması gerekebilir. Uzun süren ameliyatlar sonrası, hava yolu çevresindeki kas tonusunun azalması nedeniyle ekstübasyon güçlügü yaşabilmekte ve hastanın bir süre yoğun bakım ünitesinde izlenmesi gerekebilmektedir. ${ }^{[20]}$

MPS hastalarında hayat kalitesini, morbidite ve mortaliteyi etkileyebilen komplikasyonlar nedeniyle, cerrahi işlemlerin tüm bu risklere rağmen yapılması gerekebilmekte ve başarılı ameliyatlar yapılmaktadır. Girişimsel tüm işlemlerin, MPS hastalarında deneyimli metabolizma hastalıkları, kardiyoloji, göğüs hastalıkları, anestezi, kulak-burun-boğaz ve yoğun bakım uzmanlarının bulunduğu merkezlerde yapılması uygun olacaktır.

Mukopolisakkaridozlar, kas-iskelet sistemi tutulumunun ön planda olduğu bir lizozomal depo hastalığı grubudur. Boy kısalığı, yaygın eklem kontraktürleri, kifoz, kraniyoservikal bileşke darlığı, karpal tünel sendromu, tetik parmak, kalça displazisi, genu valgum, önde gelen ortopedik sorunlardandır. Mevcut medikal tedavilerin MPS'lerde görülen ortopedik sorunların önlenmesi ve tedavisi konusunda etkinliğinin düşük olması ve hastalığın ilerleyici seyri nedeniyle, hastalarda ortopedik cerrahi girişimler sıklıkla gerekmektedir. Tanı ve tedavi olanaklarının giderek gelişmekte olduğu bu hastalık grubunda erken yaşlarda görülen ortopedik bulgular, erken tanı ve tedavi şansı sağlayabilmektedir. MPS'lerin tedavisi, mutlaka ortopedistlerin de katıldığı multidisipliner bir ekip tarafından düzenlenmelidir.

\section{KAYNAKLAR}

1. Parenti G, Wraith EJ. The Mucopolysaccharidoses. In: Thöny B, Duran M, Gibson KM, Dionisi-Vici C, editors. Physician's Guide to the Diagnosis, Treatment, and Follow-up of Inherited Metabolic Diseases. Heidelberg: Springer; 2014. p.449-64.

2. Kılınç M. Mukopolisakkaridoz tip VI hastalarında enzim replasman tedavisi sonuçları. Ankara: Çocuk Metabolizma Hastalıkları, Hacettepe Üniversitesi; 2011.

3. Wraith EJ. Mucopolysaccharidoses and Oligosaccharidoses. In: Saudubray J, van den Berghe G, Walter JH, editors. Inborn Metabolic Diseases, 5th ed. Heidelberg: Springer; 2012. p.580-5.

4. White KK. Orthopaedic aspects of mucopolysaccharidoses. Rheumatology (Oxford) 2011;50 Suppl 5:v26-33. Crossref

5. Holt JB, Van Heest AE, Shah AS. Hand disorders in children with mucopolysaccharide storage diseases. J Hand Surg Am 2013;38(11):2263-6. Crossref

6. Zuber Z, Rozdzynska-Swiatkowska A, Jurecka A, TylkiSzymanska $A$. The effect of recombinant human iduronate2 -sulfatase (Idursulfase) on growth in young patients with mucopolysaccharidosis type II. PLoS One 2014;9(1):e85074. Crossref

7. Tomatsu S, Almeciga-Diaz CJ, Montano AM, Yabe H, Tanaka A, Dung VC, Giugliani R, Kubaski F, Mason RW, Yasuda E, Sawamoto K, Mackenzie W, Suzuki Y, Orii KE, Barrera LA, Sly WS, Orii T. Therapies for the bone in mucopolysaccharidoses. Mol Genet Metab 2015;114(2):94-109. Crossref

8. Furujo M, Kubo T, Kosuga M, Okuyama T. Enzyme replacement therapy attenuates disease progression in two Japanese siblings with mucopolysaccharidosis type VI. Mol Genet Metab 2011;104(4):597-602. Crossref

9. Gabrielli O, Clarke LA, Bruni S, Coppa GV. Enzymereplacement therapy in a 5-month-old boy with attenuated presymptomatic MPS l:5-year follow-up. Pediatrics 2010;125(1):e183-7. Crossref

10. Tajima G, Sakura N, Kosuga M, Okuyama T, Kobayashi M. Effects of idursulfase enzyme replacement therapy for Mucopolysaccharidosis type II when started in early infancy: comparison in two siblings. Mol Genet Metab 2013;108(3):172-7. Crossref

11. Solanki GA, Martin KW, Theroux MC, Lampe C, White KK, Shediac R, Lampe CG, Beck M, Mackenzie WG, Hendriksz CJ, Harmatz PR. Spinal involvement in mucopolysaccharidosis IVA (Morquio-Brailsford or Morquio A syndrome): presentation, diagnosis and management. J Inherit Metab Dis 2013;36(2):339-55. Crossref

12. Tandon V, Williamson JB, Cowie RA, Wraith JE. Spinal problems in mucopolysaccharidosis I (Hurler syndrome). J Bone Joint Surg Br 1996;78(6):938-44.

13. Lampe C, Lampe C, Schwarz M, Muller-Forell W, Harmatz $P$, Mengel E. Craniocervical decompression in patients with mucopolysaccharidosis VI: development of a scoring system to determine indication and outcome of surgery. J Inherit Metab Dis 2013;36(6):1005-13. Crossref

14. Mollmann C, Lampe CG, Müller-Forell W, Scarpa M, Harmatz P, Schwarz M, Beck M, Lampe C. Development of a Scoring System to Evaluate the Severity of Craniocervical Spinal Cord Compression in Patients with Mucopolysaccharidosis IVA (Morquio A Syndrome). JIMD Rep 2013;11:65-72. Crossref

15. Van Meir N, De Smet L. Carpal tunnel syndrome in children. J Pediatr Orthop B 2005;14(1):42-5.

16. Ryzewicz M, WolfJM. Trigger digits: principles, management, and complications. J Hand Surg Am 2006;31(1):135-46. 
17. Ashby E, Baker M, Eastwood DM. Characterization of Hip Morphology in Children With Mucopolysaccharidosis Types I and II. J Pediatr Orthop 2016;36(4):370-5. Crossref

18. Langereis EJ, Borgo A, Crushell E, Harmatz PR, van Hasselt PM, Jones SA, Kelly PM, Lampe C, van der Lee JH, Odent T, Sakkers R, Scarpa M, Schafroth MU, Struijs PA, Valayannopoulos V, White KK, Wijburg FA. Treatment of hip dysplasia in patients with mucopolysaccharidosis type I after hematopoietic stem cell transplantation: results of an international consensus procedure. Orphanet J Rare Dis 2013;8:155. Crossref
19. Cooper GA, Southorn T, Eastwood DM, Bache CE. Lower Extremity Deformity Management in MPS IVA, Morquio-Brailsford Syndrome: Preliminary Report of Hemiepiphysiodesis Correction of Genu Valgum. J Pediatr Orthop 2016;36(4):376-81. Crossref

20. Walker R, Belani KG, Braunlin EA, Bruce IA, Hack H, Harmatz PR, Jones S, Rowe R, Solanki GA, Valdemarsson B. Anaesthesia and airway management in mucopolysaccharidosis. J Inherit Metab Dis 2013;36(2):211-9. Crossref 